\title{
Working Capital Management in AVR Manufacturers Pvt Ltd, Chennai
}

\author{
S Praveen Kumar, Kirthi, Prasath Alias Surendhar
}

\begin{abstract}
This endeavor deals with the "A Study on Working Capital Management with reference to AVR Manufacturers". Working Capital Management is stressed over the issues that develop while attempting to manage the present assets, the present liabilities and the cover relationship that exist between them. The target of Working Capital Management is to manage the affiliation's present assets and current liabilities in such way that the pleasing level of Working Capital is referenced. The present assets should be tremendous enough to cover its present liabilities in order to ensure a reasonable edge of the security. [1],[3],[5]

The examination of Working Capital relies upon instruments like Trend Analysis, Ratio Analysis, Working Capital impact, working cycle, etc. Further the examination relies upon latest 5 years Annual Reports of AVR Manufacturers. Besides, even factors like contender's assessment, industry examination were not considered while setting up this errand. For this assessment the discretionary data gathering method is used. The data aggregation was away for examination of Working Capital organization of the association. There is a necessity for Working Capital as present points of interest for plan with the issue rising out of nonattendance of speedy affirmation of cash against items sold. Thusly satisfactory Working Capital is critical to help arrangements activity. This examination has a bit of the limitations like obliged data, confined period, compelled area and the term of the assessment is low. [2 ],[ 4],[6]

Keywords : working capital,participation,management
\end{abstract}

\section{INTRODUCTION}

Workers' Each running business needs working capital. Indeed, even a business which is completely outfitted with a wide range of fixed resources required will undoubtedly fall without (I) sufficient supply of crude materials for handling; (ii) money to pay for wages, influence and different costs; (iii) making a load of completed merchandise to nourish the market request consistently; and, (iv) the capacity to allow credit to its clients. All these require working capital. Working capital is in this manner like the backbone of a business. The business won't almost certainly carry on everyday exercises without the accessibility of sufficient working capital. [7],[9], [11]

Working capital cycle includes changes and turn of different constituents/segments of the working capital. At first 'money'

Revised Manuscript Received on July 22, 2019

S.Praveen Kumar, Department of MBA, Bharath Institute of Higher Education and Research, Tamilnadu, India. Email: praveenkumar.mba@bharathuniv.ac.in

Kirthi*, Department of MBA, Bharath Institute of Higher Education and Research, Tamilnadu, India. Email: kirthimba@gmail.com

Prasath Alias Surendhar, Department of Biomedical Engineering, Bharath Institute of Higher Education and Research, Tamilnadu, India. Email: mail.surendhar@gmail.com is changed over into crude materials. In this way, with the use of fixed resources bringing about worth increases, the crude materials get changed over into work in procedure and afterward into completed products. At the point when sold using a loan, the completed products accept the type of borrowers who give the business money on due date. In this manner 'money' accept its unique structure again toward the part of the bargain working capital cycle yet in the course it goes through different types of current resources as well. This is the manner by which different segments of current resources continue changing their structures because of worth expansion. Thus, they pivot and business activities proceed. In this manner, the working capital cycle includes turn of different constituents of the working capital. While dealing with the working capital, two attributes of current resources ought to be remembered viz. [8],[10] ,[12]

short life expectancy, and quick change into other type of current resource. Every constituent of current resource has similarly short life expectancy. Venture stays in a specific type of current resource for a brief period. The life expectancy of current resources relies on the time required in the exercises of acquisition; generation, deals and accumulation and level of synchronization among them. [13], [15] ,[ 17]

A short life expectancy of current resources results into quick change into other type of current resources for a running business. These qualities have certain ramifications:

I) Decision with respect to the board of the working capital must be taken habitually and on a recurrent premise.

ii) The different parts of the working capital are firmly related and bungle of any one segment unfavorably influences different segments as well. [14],[ 16], [18]

iii) The distinction between the present worth and the book estimation of benefit isn't noteworthy.

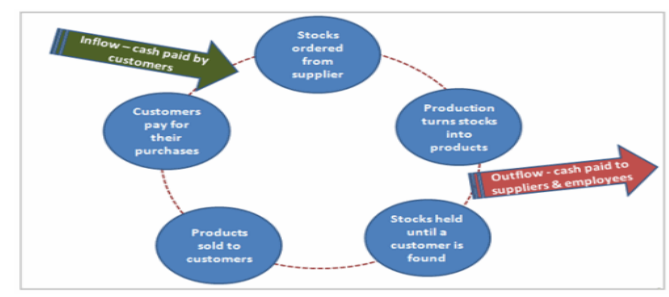

Fig:1 
Fig: 2 LIQUID RATIO

II. STATISTICAL TOOLS USED:

The study employs the following analytical tools:

- Schedule of changes in Working Capital

- Ratio Analysis.

- Correlation

- Trend Analysis

\section{III.RATIO ANALYSIS}

TABLE:1 CURRENT RATIO

\begin{tabular}{|l|l|l|l|}
\hline & & $\begin{array}{l}\text { Current } \\
\text { Liabilities } \\
\text { (Rs. In } \\
\text { Lakhs) }\end{array}$ & $\begin{array}{l}\text { Current } \\
\text { Ratio } \\
\text { (In } \\
\text { Yimes) }\end{array}$ \\
\hline 2012 & 37876.57 & 30416.58 & 1.25 \\
\hline 2013 & 38804.52 & 33405.62 & 1.16 \\
\hline 2014 & 64477.00 & 100771.80 & 0.64 \\
\hline 2015 & 93887.61 & 136628.12 & 0.69 \\
\hline 2016 & 82740.68 & 141382.71 & 0.59 \\
\hline
\end{tabular}

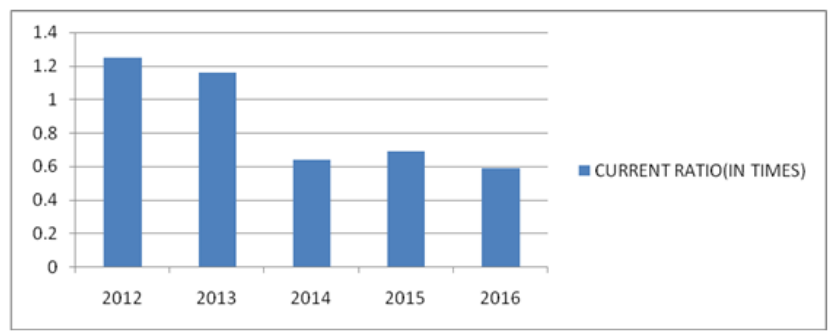

Fig:1 CURRENT RATIO

Table:2 LIQUID RATIO

\begin{tabular}{|l|l|l|l|}
\hline Years & $\begin{array}{l}\text { Liquid Assets } \\
\text { (Rs. In Lakhs) }\end{array}$ & $\begin{array}{l}\text { Current Liabilities } \\
\text { (Rs. In Lakhs) }\end{array}$ & $\begin{array}{l}\text { Liquid Ratio } \\
\text { (In Times) }\end{array}$ \\
\hline 2012 & 18740.98 & 30416.58 & 0.62 \\
\hline 2013 & 21893.22 & 33405.62 & 0.66 \\
\hline 2014 & 43976.84 & 100771.80 & 0.44 \\
\hline 2015 & 39032.49 & 136628.12 & 0.29 \\
\hline 2016 & 36223.85 & 141382.71 & 0.26 \\
\hline
\end{tabular}

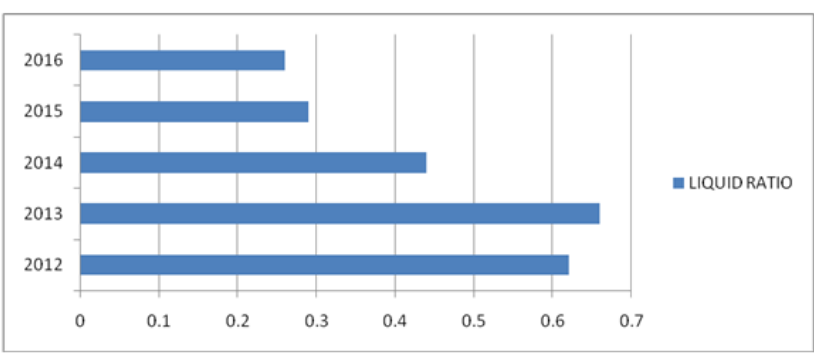

Retrieval Number: B13340882S819/2019@BEIESP
Table:3 ABSOLUTE LIQUID RATIO

\begin{tabular}{|r|r|c|l|}
\hline \multicolumn{2}{|r|}{\begin{tabular}{|r|r|}
\multicolumn{1}{|l|}{ Years } \\
Cash \\
(Rs. In Lakhs)
\end{tabular}} & $\begin{array}{l}\text { Current Liabilities } \\
\text { (Rs. In Lakhs) }\end{array}$ & $\begin{array}{l}\text { Absolute Liquid Ratio } \\
\text { (In Times) }\end{array}$ \\
\hline 2012 & 1767.15 & 30416.58 & 0.06 \\
\hline 2013 & 1936.31 & 33405.62 & 0.06 \\
\hline 2014 & 1222.00 & 100771.80 & 0.01 \\
\hline 2015 & 1973.52 & 136628.12 & 0.01 \\
\hline 2016 & 2450.54 & 141382.71 & 0.02 \\
\hline
\end{tabular}

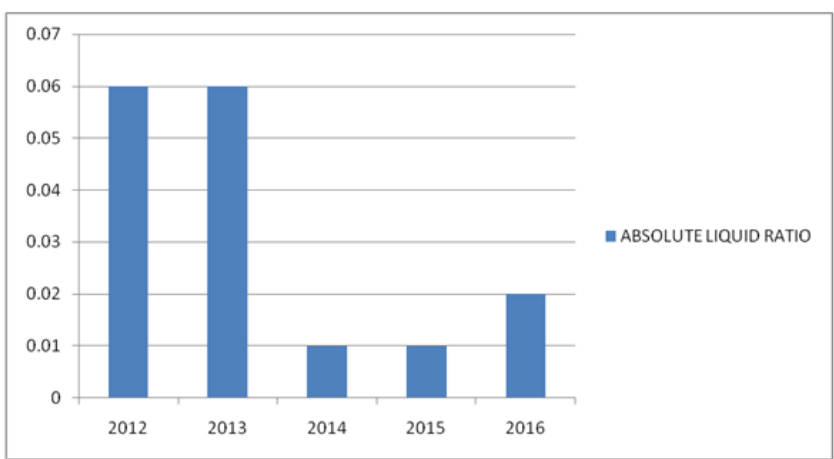

Fig: 3 ABSOLUTE LIQUID RATIO

Table:4 GROSS PROFIT RATIO

\begin{tabular}{|l|l|l|l|}
\hline Years & $\begin{array}{l}\text { Gross Profit } \\
\text { (Rs in Lakhs) }\end{array}$ & $\begin{array}{l}\text { Net Sales } \\
\text { (Rs in Lakhs) }\end{array}$ & $\begin{array}{l}\text { Gross Profit Ratio } \\
\text { (In \%) }\end{array}$ \\
\hline 2012 & 13931.36 & 106646.31 & 13.06 \\
\hline 2013 & 14988.56 & 102567.74 & 14.61 \\
\hline 2014 & 16499.38 & 120849.64 & 13.65 \\
\hline 2015 & 2522.77 & 152291.83 & 1.66 \\
\hline 2016 & 12610.63 & 186125.75 & 6.78 \\
\hline
\end{tabular}

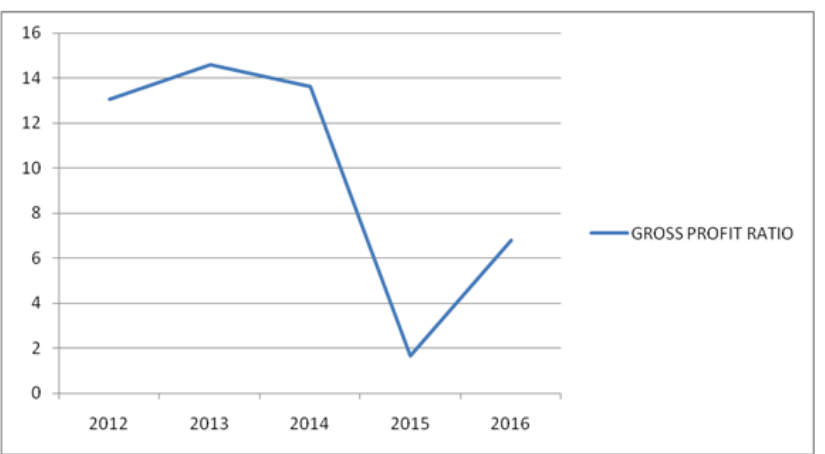

Fig: 4 GROSS PROFIT RATIO

Published By: 
International Journal of Recent Technology and Engineering (IJRTE) ISSN: 2277-3878, Volume-8, Issue-2S8, August 2019

Table:5

\begin{tabular}{|c|c|c|c|c|}
\hline \multicolumn{5}{|c|}{ Sched ule of Changes in Working Capital -2013 \& 2014} \\
\hline \multirow[b]{2}{*}{ Particulars } & \multirow[b]{2}{*}{2013} & \multirow[b]{2}{*}{2014} & \multicolumn{2}{|c|}{ Changes in Working Capital } \\
\hline & & & Increase & Decrease \\
\hline \multicolumn{5}{|l|}{ Current assets: } \\
\hline Inventories & 16911.3 & 20500 & 3588.7 & \\
\hline Trade receivables & 19956.91 & 20585.34 & 628.43 & \\
\hline $\begin{array}{l}\text { Cash\& } \\
\text { equivalents }\end{array}$ & 1936.31 & 1222 & & 714.31 \\
\hline Short term loan & Nil & 21172.96 & 21172.96 & \\
\hline Other current asaets & Nil & 996.54 & 996.54 & \\
\hline Total $(A)$ & 38804.52 & 64476.84 & & \\
\hline \multicolumn{5}{|l|}{ Current liabilities } \\
\hline Short term borrowings & 2827.06 & 40631.23 & & 37804.17 \\
\hline Trade payables & 13983.69 & 19848.46 & & 5864.77 \\
\hline $\begin{array}{ll}\text { Other current } \\
\text { liabilities }\end{array}$ & 5685.98 & 34050.53 & & 28364.55 \\
\hline Short term provisions & 10908.89 & 6241.58 & 4667.31 & \\
\hline Total(B) & 33405.62 & 100771.8 & & \\
\hline $\begin{array}{l}\text { Net Working Capital } \\
\text { (A-B) }\end{array}$ & 5398.9 & (36294.96) & & \\
\hline $\begin{array}{l}\text { Decrease in working } \\
\text { capital }\end{array}$ & 41693.86 & & 41693.86 & \\
\hline Total & $(36294.96)$ & $(36294.96)$ & 72747.8 & 72747.8 \\
\hline
\end{tabular}

\begin{tabular}{|c|c|c|c|c|}
\hline \multicolumn{5}{|c|}{ Sched ule of Changes in Working Capital - 2012 \& 2013} \\
\hline \multirow[b]{2}{*}{ Particulars } & \multirow[b]{2}{*}{2012} & \multirow[b]{2}{*}{2013} & \multicolumn{2}{|c|}{ Changes in Working Capital } \\
\hline & & & Increase & Decrease \\
\hline \multicolumn{5}{|l|}{ Current assets: } \\
\hline Inventories & 19135.59 & 16911.3 & & 2224.29 \\
\hline Trade receivables & 16473.83 & 19956.91 & 3483.08 & \\
\hline $\begin{array}{ll}\text { Cash\& } & \text { cash } \\
\text { equivalents }\end{array}$ & 1767.15 & 1936.31 & 169.16 & \\
\hline Short term loan & pil & pil & & \\
\hline Other current assets & pil & pil & & \\
\hline Total(A) & 37376.57 & 38804.52 & & \\
\hline \multicolumn{5}{|l|}{ Current liabilities } \\
\hline Short term borrowings & 2556.6 & 2827.06 & & 270.46 \\
\hline Trade payables & 11904.29 & 13983.69 & & 2079.4 \\
\hline Other current liabilities & 5864.25 & 5685.98 & 178.27 & \\
\hline short term provisions & 10091.37 & 10908.89 & & 817.52 \\
\hline Total(B) & 30416.51 & 33405.62 & & \\
\hline $\begin{array}{l}\text { Net Working Capital } \\
(A-B)\end{array}$ & 6960.06 & 5398.9 & & \\
\hline $\begin{array}{l}\text { Decrease in working } \\
\text { capital }\end{array}$ & & 1561.16 & 1561.16 & \\
\hline Total & 6960.06 & 6960.06 & 5391.67 & 5391.67 \\
\hline
\end{tabular}

\begin{tabular}{|c|c|c|c|c|c|}
\hline Year & Sales $(X)$ & $\mathrm{Wc}(\mathrm{Y})$ & $x^{2}$ & $\mathrm{Y}^{2}$ & $\mathrm{XY}$ \\
\hline 2012 & 106646.31 & 7459.99 & 11373435436.6161 & 55651450.8001 & 795580406.1369 \\
\hline 2013 & 102567.74 & 5398.9 & 10520141288.7076 & 29148121.21 & 553752971.486 \\
\hline 2014 & 120849.64 & -36294.8 & 14604635488.129 & 1317312507.04 & -4386213513.872 \\
\hline 2015 & 152291.83 & -42740.51 & 23192801484.7489 & 1826751195.0601 & -6509030483.0333 \\
\hline 2016 & 186125.75 & -58642.03 & 34642794813.0625 & 3438887682.5209 & 10914791815.2725 \\
\hline & 668481.27 & 124818.45 & 94333808511.5152 & 6667750956.6311 & 20460702434.5549 \\
\hline
\end{tabular}

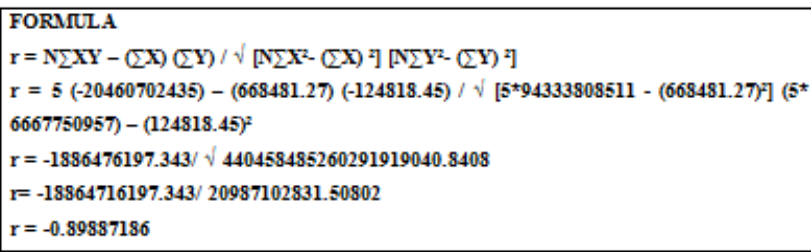

\section{RESULTS}

1. The current proportion of the organization is higher in the year 2012 with 1.24 and it was diminished to 0.59 in the year 2012-13. [19],[21],[23]

2. The organization's liquidity position is backing off to 0.26 in the year 2016 from 0.66 in the year 2013.

3. The organization's supreme fluid proportion has been expanded to 0.02 in the year 2016 from 0.01 in the year 2015 .

4. The gross benefit of the organization is expanded to 6.78 in the year 2016. 


\section{Working Capital Management in AVR Manufacturers Pvt Ltd, Chennai}

5. The net benefit of the organization is diminished to 4.91 in the year 2016 from 7.15 in the year 2015. This demonstrates a low edge of wellbeing. The organization needs to deal with the offers of the organization.

6 . The obligation value proportion of the organization is diminished to 0.59 in the year 2013 from 0.82 in the year 2012. Be that as it may, the obligation limit of the organization is step by step expanded step by step

7. The stock turnover proportion Of the organization is diminished to 4.86 in the year 2013 from 5.48 in the year 2012. Be that as it may, the expense of merchandise sold and normal stock has begun to expand step by step

8. The indebted person turnover proportion Of the organization is diminished to 5.14 in the year 2013 from 6.28 in the year 2012. In any case, it began to increment from one year from now.

9. Debtor Collection Period shows the normal time taken to gather exchange obligations. At the end of the day, a decreasing timeframe is a marker of expanding productivity.

10. The leaser turnover proportion of the organization is expanded to 1.74 in the year 2013 from 1.66 in the year 2012 and it again began to increment for next two years.

11. The organization is exploiting exchange credit accessible to it.

12. The Working Capital of the organization expanded to 19.00 occasions in the year 2013 from 14.30 occasions in the year 2012 and from there on the Working Capital of the organization has begun to diminish. [26],[28],[30]

13. The fixed resource turnover proportion is diminished to 0.49 in the year 2013 from 0.72 in the year 2012. Be that as it may, it expanded the benefit turnover proportion from quick one year from now.

14. The current resource proportion is diminished to 2.64 in the year 2013 from 2.82 in the year 2012 . Be that as it may, it step by step began to build the turnover proportion from 2012-2013.

15. The net resource turnover proportion is diminished to 0.38 in the year 2013 from 0.53 in the year 2012 and there from it began to diminish yet 2016 it began to increment at progressive level

16. The changes of Working Capital is to be diminished in the year 2016

17. The changes of Working Capital is to be diminished in the year 2012-11

18. The changes of Working Capital is to be diminished in the year 2014
19. The changes of Working Capital are to be diminished in the year 2013. In this way it demonstrates the overabundance of current resources over current liabilities is alluded to as the organization's working capital

20. The changes of Working Capital are to be expanded in the year 2012. In this manner it demonstrates the abundance of current liabilities over current resources is alluded to as the organization's negative working capital. [20],[22], [24]

\section{DISCUSSION}

1. The Company recommends to take measures for keep up the fixed resources so as to use the advantages for the business for longer than a year.

2. The organization is recommended to take measures for increment the deals, when deals are fast, little money is attached to prop the business up; which may make it simpler to extend.

3. The Management proposes to augment its income should take to the extent that this would be possible to pay its bills. In any case, there are dangers related with taking additional time than is allowed by the terms of exchange with the provider. One is the loss of provider generosity; another is the potential danger of lawful activity or late-pay. [31],[33],[32]

4. The organization proposes that to focus more on deals for gathering its better obligation limit.

5. The organization proposes that to make fundamental strides of the account holders accumulation period so as to maintain a strategic distance from the late installment.

6. The Management recommended finding a way to expanding the Working Capital so as to meet the everyday tasks. [25],[27],[29]

\section{CONCLUSION}

Working Capital is utilized in AVR Manufacturers, for the accompanying reason work in advancement, completed merchandise, inventories, sundry borrowers, and day today money prerequisites. The AVR Manufacturers keep certain subsidizes which is naturally accessible to fund the present resources necessities. The different data with respect to "Money related wellbeing the board, for example, grouping, determinants, sources have been talked about identifying with AVR Manufacturers, Ratio Analysis has been Carried out utilizing Financial Information for last five bookkeeping years for example from 2011 to 2015 Ratios like working capital Turnover Ratio, Quick Ratio, Current Ratio, Inventory Turnover Ratio, Debtor Turnover Ratio, Creditors turnover proportion have additionally been broke down. A Statement of Changes in Working Capital has additionally been investigated.

From the discovering I infeXr that the administration proposed finding a way to expanding the 
Working Capital so as to meet the everyday tasks.

It is likewise recommended to the organization to make vital strides of the indebted person's accumulation period so as to maintain a strategic distance from the late installment. The Management proposes to augment its income should take to the extent that this would be possible to pay its bills. Be that as it may, there are dangers related with taking additional time than is allowed by the terms of exchange with the provider. One is the loss of provider generosity; another is the potential risk of legitimate activity or late-pay.

The organization utilize aggregate office technique for dissecting Financial wellbeing the executives. The organization's general deals are in a beneficial position yet the Working Capital of the organization is negative because of increment under water and ebb and flow liabilities.

\section{REFERENCES}

1. G BharthVajan R., Ramachandran S.,Psychographic dimensions of training,2016,International Journal of Pharmacy and Technology,V-8,I-4,P-23727-23729

2. Balakrishnan P., Bharthvajan R.,A study on human resource planning in hospitals in Chennai City,2014,International Journal of Applied Engineering Research,V-9,I-22,P-7503-7507

3. Priyadarsini P., Bharthvajan R.,Role of emotional intelligence training programme in reducing the stress of the nurses,2014,International Journal of Applied Engineering Research,V-9,I-22,P-7411-7421

4. Kerinab Beenu G., Bharthvajan R.,Empirical analysis on the cosmetic buying behavior of young women in South India,2014,International Journal of Applied Engineering Research,V-9,I-22,P-7361-7366

5. Balakrishnan P., Bharthvajan R.,Whistling in the wind,2014,International Journal of Applied Engineering Research,V-9,I-22,P-7586-7593

6. Krishnan B., Peter M.,Health hazards of Indian Bpo employee-an alarming issue,2014,International Journal of Applied Engineering Research,V-9,I-22,P-7336-7341

7. Kerinab Beenu G.H., Peter M.,Role of insurance in economic development,2014,International Journal of Applied Engineering Research,V-9,I-22,P-7532-7539

8. Balakrishnan P., Peter M., Priyadarsini P.,Efficiency of safety measures for wellbeing of employees in manufacturing industry,2014,International Journal of Applied Engineering Research,V-9,I-22,P-7376-7382

9. Anbarasi M., Praveen Kumar S.,Online sales promotions of herbal products and its effectiveness towards tanisha.com,2019,Indian Journal of Public Health Research and Development,V-10,I-1,P-195-200

10. Anbarasi M., Praveen Kumar S., Various online marketing and promotions strategies to improve the validation towards the organic products in the pharmaceutical sectors,2019,Indian Journal of Public Health Research and Development,V-10,I-1,P-263-269

11. Loganathan R., Praveen Kumar S.,Grievance handling a key factor for solving issues of employees in an organization,2014,International Journal of Applied Engineering Research,V-9,I-22,P-7483-7491

12. Loganathan R., Praveen Kumar S.,Study on preference of private label brands in super and Hypermarkets, 2014,International Journal of Applied Engineering Research,V-9,I-22,P-7327-7335

13. Smitha M., Praveen Kumar S.,Understanding stress and its managementamong the nurses in Chennai city,2014,International Journal of Applied Engineering Research,V-9,I-22,P-7560-7565

14. Kerinab Beenu G.H., Praveen Kumar S.,A study on the investment behavior of Chennai investors in mutual fund schemes,2014,International Journal of Applied Engineering Research,V-9,I-22,P-7520-7525

15. Loganathan R., Praveen Kumar S.,Retention strategies key for organizational productivity,2014,International Journal of Applied Engineering Research,V-9,I-22,P-7443-7447

16. Pavithra J., Ganesan M., Brindha G.,State wise analysis of microfinance sector in India,2016, International Journal of Pharmacy and Technology,V-8,I-4,P-23417-23432

17. Pavithra J., Ganesan M.,A comparative study on microfinance in India and abroad,2016,International Journal of Applied Business and Economic Research,V-14,I-8,P-5471-5476

18. Pavithra J., Ganesan M.,A study on awareness and impact of micro-financial schemes,2016,International Journal of Applied Business and Economic Research,V-14,I-8,P-5449-5460
19. Senthilmurugan P., Pavithra J.,Consumer preference towards organised retailing with reference to Big Bazaar,2014,International Journal of Applied Engineering Research,V-9,I-22,P-7469-7475

20. Senthilmurugan P., Pavithra J.,Implication of social media marketing in growing healthcare industry,2014,International Journal of Applied Engineering Research,V-9,I-22,P-7448-7456

21. Loganathan R., Pavithra J.,Consumer perception towards private label brand over other brands in super markets and hypermarkets,2014,International Journal of Applied Engineering Research,V-9,I-22,P-7355-7360

22. Kerinab Beenu G., Pavithra J.,Tradeâ€"off between liquidity and profitability in logistics industry,2014,International Journal of Applied Engineering Research,V-9,I-22,P-7398-7401

23. Kerinab Beenu G., Pavithra J.,A study on the prospective consumerâ $€^{\mathbf{T M}_{\mathbf{S}}}$ perception towards utility cars in Chennai city,2014,International Journal of Applied Engineering Research,V-9,I-22,P-7526-7531

24. Pavithra J., Dilli Babu P., Ambuli T.V.,A study on budgetary control at Maruti Service Masters, Chennai,2014,International Journal of Applied Business and Economic Research,V-12,I-2,P-151-161

25. Pavithra J., Dilli Babu P., Ambuli T.V.,A study on customer satisfaction of retro Garments Pvt Ltd, Chennai,2014,International Journal of Applied Business and Economic Research,V-12,I-2,P-381-391

26. Kerinab Beenu G.H., Pavithra J., Senthilmurugan P.,A study on the influence of promotional activities for TATA ARIA among consumers in Chennai,2014,International Journal of Applied Engineering Research,V-9,I-22,P-7572-7578

27. Vijayaragavan S.P.,An investigative expert that's general FBG sensors,International Journal of Mechanical Engineering and Technology,V-8,I-8,PP-1500-1505,Y-2017

28. Vijayaragavan S.P.,Equalization routing protocol for $\mathrm{Wi}-\mathrm{Fi}$ sensor strategy,International Journal of Mechanical Engineering and Technology,V-8,I-8,PP-1662-1666,Y-2017

29. Karthik B., Kiran Kumar T.V.U., Vijayaragavan P., Bharath Kumaran E.,Design of a digital PLL using 0.35 $\hat{\mathrm{I}}^{1 / 4 \mathrm{~m}}$ CMOS technology,Middle East Journal of Scientific Research,V-18,I-12,PP-1803-1806,Y-2013

30. Kanniga E., Selvaramarathnam K., Sundararajan M.,Kandigital bike operating system,Middle - East Journal of Scientific Research,V

31. Jasmin M., Vigneshwaran T., Beulah Hemalatha S.,Design of power aware on chip embedded memory based FSM encoding in FPGA,International Journal of Applied Engineering Research,V-10,I-2,PP-4487-4496,Y-2015

32. Jasmin M.,Optimization techniques for low power VLSI circuits,MiddleEast Journal of Scientific Research,V-20,I-9,PP-1082-1087,Y-2014

33. Jasmin M., Vigneswaran T.,Fuzzy controller for error control of on - Chip communication,2017 International Conference on Algorithms, Methodology, Models and Applications in Emerging Technologies, ICAMMAET 2017,V-2017-January,I-,PP-1-5,Y-2017

\section{AUTHORS PROFILE}

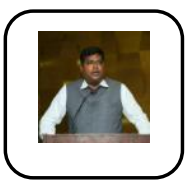

Dr.S.Praveen Kumar Professor ,Department of MBA, Bharath Institute of Higher Education and Research, Tamilnadu, India

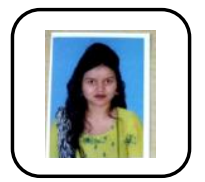

Kirthi,Student ,Department of MBA, Bharath Institute of Higher Education and Research, Tamilnadu, India

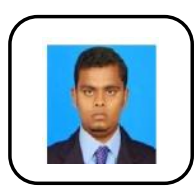

Prasath Alias Surendhar Assistant Professo ,Department of Biomedical Engineering, Bharath Institute of Higher Education and Research, Tamilnadu, India . 